\title{
СУЧАСНІ ТЕХНОЛОГІЇ ДЛЯ ОБ’ЄКТИВІЗАЦІЇ ТА СТАНДАРТИЗАЦІЇ ОЦІНЮВАННЯ ПРАКТИЧНИХ НАВИЧОК ЛІКАРІВ-ІНТЕРНІВ ХІРУРГІВ
}

\author{
O. S. Dolya, N. O. Yareshko \\ Zaporizhzhia State Medical University \\ MODERN TECHNOLOGIES FOR ASSESSMENT EVALUATION AND \\ STANDARDIZATION OF PRACTICAL SKILLS OF SURGEONS INTERNS
}

\begin{abstract}
Анотація. Реформа охорони здоров’я України, яка сьогодні відбувається, інтеграція вітчизняної медичної науки і практики у світову потребують від закладів медичної освіти підготовки сучасних медичних фахівців. Велике значення при цьому відіграє післядипломна медична освіта. Метою роботи було теоретичне обгрунтування методики об’єктивізації оволодіння практичними навичками лікаря-інтерна хірурга за період навчання в інтернатурі, використовуючи сучасні досягнення обігу цифрової інформації. Період навчання після отримання диплома лікаря, на сьогодні, називається інтернатурою і складає 36 міс., 3 них лише 12 міс. очна форма навчання. У гонитві за засвоєнням різнопланового теоретичного матеріалу відбувається нехтування детальним розглядом питань, з якими частіше стикається молодий спеціаліст. Освоєння практичних навичок більшою мірою зміщене на самостійне опрацювання в період заочної інтернатури. Для вирішення поставленого завдання було проаналізовано ряд англомовних джерел і пропонується використати розгалужені цифрові технології, глобальну мережу «Інтернет» та смартфон, який є у кожного громадянина молодого віку. В основі запропонованої інновації знаходиться «крива навчання», а також розроблений механізм об’єктивізації оцінки набутих навичок та моніторинг їх набуття on-line. Запропоновано змінення формату єдиного документа, що засвідчує зайнятість інтерна, «Щоденник обліку роботи інтерна» на електронний. Висунута ідея не потребує значних фінансових затрат, але зможе підвищити самодисципліну серед молодих спеціалістів, полегшити облік освоєних практичних навичок, а також проводити дистанційний контроль за освоєнням практичних навичок незалежно від місця розташування відділення, в якому лікар-інтерн проходить заочну частину інтернатури. Соціальним наслідком цього буде усунення ряду прихованих проблем у набутті післядипломної освіти інтернами-хірургами і як результат якісно новий формат кваліфікації молодого спеціаліста.
\end{abstract}

Ключові слова: післядипломна медична освіта; «крива навчання»; портфоліо лікаря-інтерна.

Abstract. Current reform of health care in Ukraine, the integration of local medical science and practice into the global one require that medical educational institutions have to prepare modern medical specialists. Postgraduate medical education plays an important role in this case. The purpose of the work was to develop a theoretical basis for assessing the mastery of practical skills of a surgeon intern for the entire period of study in the internship, using the modern achievements of digital technologies. The period of study after obtaining a diploma is called internship and makes 36 months and only 12 months of them - full-time education. To master all this diverse material during the year, both theoretically and practically, is impossible. We unknowingly ignore the more detailed consideration of those issues with which a young specialist will meet more often at the beginning of his independent activity, where more errors may occur. Mastering of practical skills is more shifted to independent study. The achievements of the twenty-first century, namely developed digital technologies, Internet and smartphones are able to help every young citizen with this. The proposed innovation is based on the "curve of training”, we also developed the mechanism for objectification of assessment of acquired skills, it can also be used for monitoring of their acquirement on-line. Taking into consideration that the only document certifying the employment of an intern is "Intern's Diary", we propose to change the format of its management into an electronic one. The above mentioned ideas do not require significant financial costs, but will be able to change the situation for the better already, the accounting of mastered skills will be facilitated, possibility of remote control over the mastering of skills, regardless the location of the department in which the intern works part-time. The social consequence of which will be elimination of a number of hidden problems in acquiring postgraduate education by intern surgeons and as a result a qualitatively new qualification format for a young specialist.

Key words: post-graduate education; “curve of training”; intern’s portfolio. 
Вступ. В умовах сьогодення відбувається багато змін у галузі освіти та охорони здоров'я України. Проте осторонь залишається післядипломна освіта, що призводить до виникнення внутрішніх конфліктів між застарілими догмами та вимогами до кваліфікації молодого лікаря. Сучасний світ, що динамічно змінюється, вимагає змін і у викладанні медичної освіти, особливо після отримання диплома, набуття так званої спеціалізації.

Медична спільнота різних країн світу по-різному організувала власні системи охорони здоров'я та медичну освіту. Проте, незважаючи на різні здобутки, є спільні проблеми у її набутті, отже, їх можна вирішити, використовуючи схожі прийоми. Раціонально організована система освіти здатна не тільки самовідтворюватись, але й продукувати нові висококваліфіковані кадри як у науковому, так і в практичному руслі, плекаючи принципи академічної добропорядності [2].

Окремо слід зауважити, що на сьогодні в Україні $€$ унікальні умови, коли можна, спираючись на позитивний досвід країн Європи чи Америки, побудувати нове медико-освітнє середовище з кращими міжнародними стандартами як для медичної освіти, так і для медичної практики. Також не потрібно нехтувати і деякими негативними явищами реформ, як побічним продуктом, що частіше виникає у більш пізній період, і який ми також спостерігаємо у розвинених моделях західних країн.

Особливості менталітету, сучасний стан медичної спільноти в Україні, ії статичність та небажання або нерозуміння змін на кожній ланці як освітнього процесу, так і практичної медицини створюють багато перешкод для впровадження нових ідей $[3,4]$.

Мета статті - розробка теоретичного обгрунтування оцінювання оволодіння практичними навичками лікаря-інтерна хірурга за весь період навчання в інтернатурі, використовуючи сучасні досягнення обігу цифрової інформації.

Теоретична частина. На сьогодні період навчання після отримання диплома лікаря називається інтернатурою. За радянські часи цей термін складав 1 рік або 1,5 року для хірургічних спеціальностей, але його замало для отримання висококваліфікованого спеціаліста. Тому запровадили збільшення терміну навчання в інтернатурі, але директив, по якісному наповненню збільшеного часу навчання, не надали. Якщо не вдаватися в подробиці, то пересічний громадянин скаже: наприклад, у хірургії, за 3 роки (36 міс.) можна вишколити будь-якого лікаря будь-чому у всіх субспеціальностях та підрозділах.
Але така ситуація мала б право на існування, якби були університетські клініки, де інтерн перебував би весь період навчання, де відбувалися б ротації відділень від загальних до вузько направлених. Але, на жаль, в Україні не склалася така практика та й не була надана найменша матеріальна база університетам для створення своїх клінік.

Відповідно до основного документа, що регулює всі взаємовідносини, Положення про інтернатуру, період навчання складається з очної та заочної форм. Очна форма, коли інтерн перебуває на базі медичного університету, де є викладачі, а заочна коли працює у відділенні лікувального закладу. На практиці часто виявляється, що відділення лікарень не $є$ базами університету, більше того, вони можуть навіть бути значно територіально розмежовані, знаходитися в інших містах чи сусідніх областях. I тут виникають питання, хто проводить навчання у лікарні, як здійснюється контроль оволодіння навичками. Якщо базою заочного навчання є майбутнє місце роботи, а завідувач відділення зацікавлений у навчанні молодого спеціаліста, то успіх у вирішенні цього питання якоюсь мірою реалізується, бо $є$ мотивація. В іншому випадку все може бути набагато гірше. Сучасна модель побудови економіки базується на засадах конкуренції. Тому все навчання лікаря-інтерна може бути зведено до спостереження за лікувально-діагностичним процесом осторонь, бо персонал лікарні просто ігнорує його присутність. Крім того, не отримуючи повною мірою всієї реальної інформації про практичне навчання поза межами ВН3, неможливо швидко i чітко реагувати та змінювати ситуацію на краще.

На першому році навчання очна форма займає 6 міс., на 2 році - 4 міс., на 3 році - 2 міс. Всього 12 з 36 місяців. Щодо інформаційного наповнення, якщо протягом 12 міс. вивчати лише абдомінальну хірургію, то на кінець навчання наші випускники могли б досить впевнено почуватися на самостійних чергуваннях по наданню невідкладної абдомінальної хірургічної допомоги. Але відповідно до Типового навчального плану та програми спеціалізації за спеціальністю «Хірургія», підписаного заступником міністра охорони здоров'я України О. Лінчевським у 2017 р., за ці 12 міс. потрібно розглянути майже всі питання всієї хірургії, яка включає в себе: торакальну хірургію, абдомінальну хірургію, проктологію, хірургічні захворювання ендокринних органів, хірургічні захворювання судин, трансплантологію, гнійні хірургічні захворювання, опіки та відмороження, амбулаторну хірургію, 
невідкладну гінекологію, невідкладну урологію, дитячу хірургію, онкологію, травматологію та ортопедію, нейрохірургію. Засвоїти весь цей різноплановий матеріал за рік - чи це реально - так, але надати практики, яка зможе закріпити отримані знання, - НI. Тому виходить, що в гонитві за засвоєнням теоретичного матеріалу ми несвідомо нехтуємо більш детальним розглядом тих питань, з якими частіше буде стикатися молодий спеціаліст на початку своєї самостійної діяльності, де можливе виникнення більшої кількості помилок.

У раніше наведеному документі $є$ дуже детальний «Перелік практичних навичок та операційних втручань», якими повинен оволодіти лікар-інтерн. Але як підтвердити реальність виконання і рівень засвоєння практичних навичок - невідомо. Перевірка загалом зводиться до співбесіди на тему методики виконання випадкової навички, або випадкової оперативної техніки. Для хірургії, як розділу медицини, де основна частина це «praxis», співбесіда не може бути основою оцінювання.

До звітної документації інтерна належить «Щоденник обліку роботи інтерна», який повинен вестися щодня і відображати все, що інтерн виконував. Але не вся робота, що виконується інтерном у відділенні, направлена на підтвердження чи засвоєння саме потрібних програмних навичок. Тому щоденники, які ведуться в довільній формі, не дають необхідної інформації щодо рівня підготовки лікаря-інтерна.

Вихід $з$ цієї ситуації $є$, і знаходиться він завдяки досягненням XXI століття, а саме: розгалуженим цифровим технологіям, глобальній мережі «Інтернет» та смартфону в кожного пересічного громадянина молодого віку. Тут доречно згадати про таке теоретичне поняття, як «крива навчання» (див. рис. 1) [6], особливо в аспекті освоєння прикладних, а не теоретичних знань, та цитату одного з відомих діячів сьогодення: «Рівень майстерності залежить лише від кількості правильно виконаних повторів» (д-р мед. наук, проф., чл.-кор. РАН О. Е. Луцевич).

Розглядаючи графік, зображений на рис. 1, можна бачити залежність набутого досвіду (дуга) від кількості випадків (n) по осі абсцис та терміну навчання (t) по осі ординат. Так, зі збільшенням кількості виконаних навичок та терміну навчання відбувається збільшення набутого досвіду, а значить покращуються результати виконаної роботи, до певного періоду, коли крива навчання займає горизонтальне положення і значного покращення результатів не відбувається, незалежно від терміну навчання та кількості виконаних навичок. (t) $\uparrow$

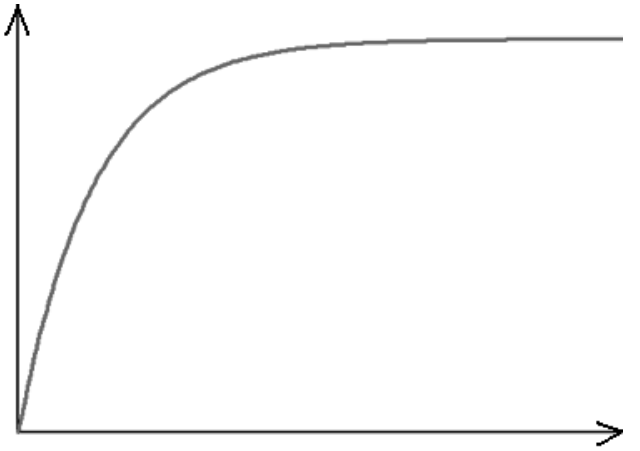

(n)

Рис. 1. Усереднена крива навчання. Залежність набутого досвіду від терміну навчання та кількості вправ.

Отже, для того щоб оволодіти тією чи іншою методикою, її потрібно виконати декілька разів, i кожний наступний раз буде мати кращий результат, ніж попередній, допоки не буде досягнуто «плато». Серед анестезіологів Західної Європи було проведено дослідження, метою якого було виявити, після скількох, мінімально, виконаних інтубацій майстерність методики, що проводиться, значним чином не зростає. Такою кількістю виявилось 200 маніпуляцій, тобто не має значення, чи це 201 інтубація, чи тисячна - техніка залишається сталою. Це наочний приклад «кривої навчання».

Для полегшення ведення обліку потрібно визначитися з обов'язковими навичками та другорядними. Лікар-інтерн може оволодіти всіма навичками згідно з програмою, але має бути програма мінімум - ті навички, які обов'язкові для кожного і які лікар-інтерн повинен виконувати самостійно. При цьому кількість повторів за період інтернатури має бути не менше 50. Це та мінімальна кількість навичок, які будуть виконані під наглядом досвідченого спеціаліста, що забезпечить належне освоєння техніки виконання, при цьому буде враховано більшість помилок на етапах освоєння. Проводячи огляд зарубіжної літератури, схожі ідеї виказує Daniel J. Reichenbach зі співавторами при розгляді питання осовоєння лапароскопічної резекції ободової кишки [5]. Облік виконаних навичок повинен вести куратор групи. Існуюча на сьогодні формула про те, що диплом спеціаліста отримує кожний, хто дочекається закінчення 3 років навчання, буде скасована [1].

Повертаючись до звітних документів лікаряінтерна, є пропозиція змінення формату ведення щоденника на електронний. Тобто створення облікового запису на певному інтернет-ресурсі, куди будуть вноситися дані щодо об'єму виконаних робіт. Вносити дані необов'язково записом у 
Word, простіше виконувати фотофіксацію протокольованої роботи - виконаних навичок - 3 історії хвороби - «Медична карта стаціонарного хворого». Тим самим буде:

1. Економія часу по веденню обліку.

2. Об'єктивізація процесів оволодіння навичками.

3. Контроль процесів у режимі реального часу on-line.

4. Виникає досі невідоме явище, а саме конкуренція серед інтернів за першість, яка може заохочуватися різними способами.

5. Учасники групи можуть бачити успіхи один одного, це спонукає їх до більш активної роботи і доброчесної фіксації виконаних робіт.

6. Неочікуваний побічний продукт запропонованого нововведення - створення власного портфоліо досягнень та умінь. Такий продукт стане невдовзі дуже затребуваним на ринку праці з високою конкуренцією в якості об’єктивної характеристики спеціаліста.

Увесь зібраний матеріал можна розформувати по різних теках, які будуть названі відповідною навичкою. Навичку можна вважати успішно засвоєною після досягнення необхідної кількості повторів, тобто окремих фотофайлів.

У Запорізькому державному медичному університеті на сьогодні створені всі умови для провадження запропонованих ідей у практику. Залишається лише ряд технічних питань із визначенням інтернет-ресурсу, на якому буде відбуватися збір інфор-

\section{Список літератури}

1. Сафонова И. Ужасы медицинского образования, или как учится врач [Электронный ресурс] / И. Сафонова // Український інформаційний портал «ТСН». - 2015. 28 верес. - Режим доступу : www.ru.tsn.ua.

2. Совсун I. Реформа медичної освіти - це критично важливо [Електронний ресурс] / I. Совсун, О. Лінчевський // Дзеркало тижня. Україна : міжнар. громад.-політ. тижневик. - 2018. - Вип. № 16 (28 квіт. - 11 трав.). Режим доступу : www.dt.ua.

3. Тернова С. Реформа медичної освіти: чи досяжна американська мрія? [Електронний ресурс] / С. Тернова // Ваше здоров'я : Всеукр. мед. газ. - 2017. - 19 трав. - Режим доступу : www.vz.kiev.ua.

\section{References}

1. Safonova, I. (2015). Uzhasy meditsinskogo obrazovaniya, ili kak uchitsya vrach-2 [The horrors of medical education or how to become a doctor 2]. Ukrainian information portal TSN [in Ukrainian]. мації, питання пов'язані з безпосереднім освоєнням ресурсу викладачами та інтернами. Крім того, не потрібно забувати про погодження запропонованої новації з адміністраціями лікувальних закладів та управлінь охорони здоров'я. Результати пілотного дослідження будуть викладені у наступних публікаціях.

Висновки та перспективи подальших досліджень. Зміни у веденні звітної документації дозволять вирішити багато прихованих проблем. Насамперед:

1. Підвищиться самодисципліна серед молодих спеціалістів. Зменшиться кількість паперових носіїв, які аналізувати вкрай важко.

2. Полегшиться облік освоєних навичок.

3. Можливий дистанційний контроль за освоєнням навичок незалежно від місця розташування відділення, в якому лікар-інтерн проходить заочну частину інтернатури.

Окрім того, якщо лікар-інтерн не зможе освоїти певну частину матеріалу через об'єктивну причину - недостатню «потужність» відділення, можливо буде оперативно відреагувати заміною відділення.

Застосування викладених ідей у реальних умовах буде основою пілотного дослідження впливу змін на результати освоєння практичних навичок.

Запропоновані новації не потребують великих матеріальних затрат і маємо надію, що вже зараз зможуть змінити ситуацію на краще у формуванні молодого спеціаліста.

4. Уляницький Д. Вчити по-американськи: як МОЗ реформує медичну освіту [Електронний ресурс] / Д. Уляницький // Українське інформаційне агентство «РБКУкраїна». - 2018. - 14 верес. - Режим доступу : www. daily.rbc.ua.

5. Laparoscopic colon resection early in the learning curve / J. Daniel Reichenbach, A. Darrel Tackett, James Harris [et al.] // Ann Surg. - 2006. - Vol. 243 (6). - P. 730-737.

6. Ritter F. E. The learning curve. In International Encyclopedia of the Social and Behavioral Sciences / F. E. Ritter, L. J. Schooler. - Amsterdam : Pergamon, 2002. - P. 86028605.

2. Sovsun, I., \& Linchevskyi, O. (2018). Reforma medychnoi osvity - tse krytychno vazhlyvo [The reformation of medical education is extremely importnant]. Dzerkalo tyzhnia - Weekly Mirror, 16 [in Ukrainian]. 
3. Ternova, S. (2017). Reforma medychnoi osvity: chy dosiazhna amerykanska mriia? [Reform of medical education: Can the American dream come true?]. Vashe zdorove - Your health [in Ukrainian].

4. Ulianytskyi, D. (2018). Vchyty po amerykansky: yak MOZ reformuie medychnu osvitu [American learning: How does the Ministry of Health reform medical education?]. Kyiv: "RBK-Ukraine” [in Ukrainian].
5. Daniel J. Reichenbach, Darrel Tackett, A., James Harris, Diego Camacho, Edward A. Graviss, Brendan Dewan, B.S., ... John F. Sweeney (2006). Laparoscopic colon resection early in the learning curve. Ann. Surg., 243 (6), 730-737.

6. Ritter, F.E., \& Schooler, L.J. (2002). The learning curve. In International Encyclopedia of the Social and Behavioral Sciences. Amsterdam: Pergamon. 